This item was submitted to Loughborough's Research Repository by the author.

Items in Figshare are protected by copyright, with all rights reserved, unless otherwise indicated.

\title{
Cost benefit analysis approach to global claims
}

PLEASE CITE THE PUBLISHED VERSION

http://dx.doi.org/10.1108/17561451111178434

PUBLISHER

(C) Emerald

VERSION

AM (Accepted Manuscript)

LICENCE

CC BY-NC-ND 4.0

REPOSITORY RECORD

Lord, Wayne E., and T.E. Gray. 2019. "Cost Benefit Analysis Approach to Global Claims". figshare. https://hdl.handle.net/2134/8959. 
This item was submitted to Loughborough's Institutional Repository (https://dspace.lboro.ac.uk/) by the author and is made available under the following Creative Commons Licence conditions.

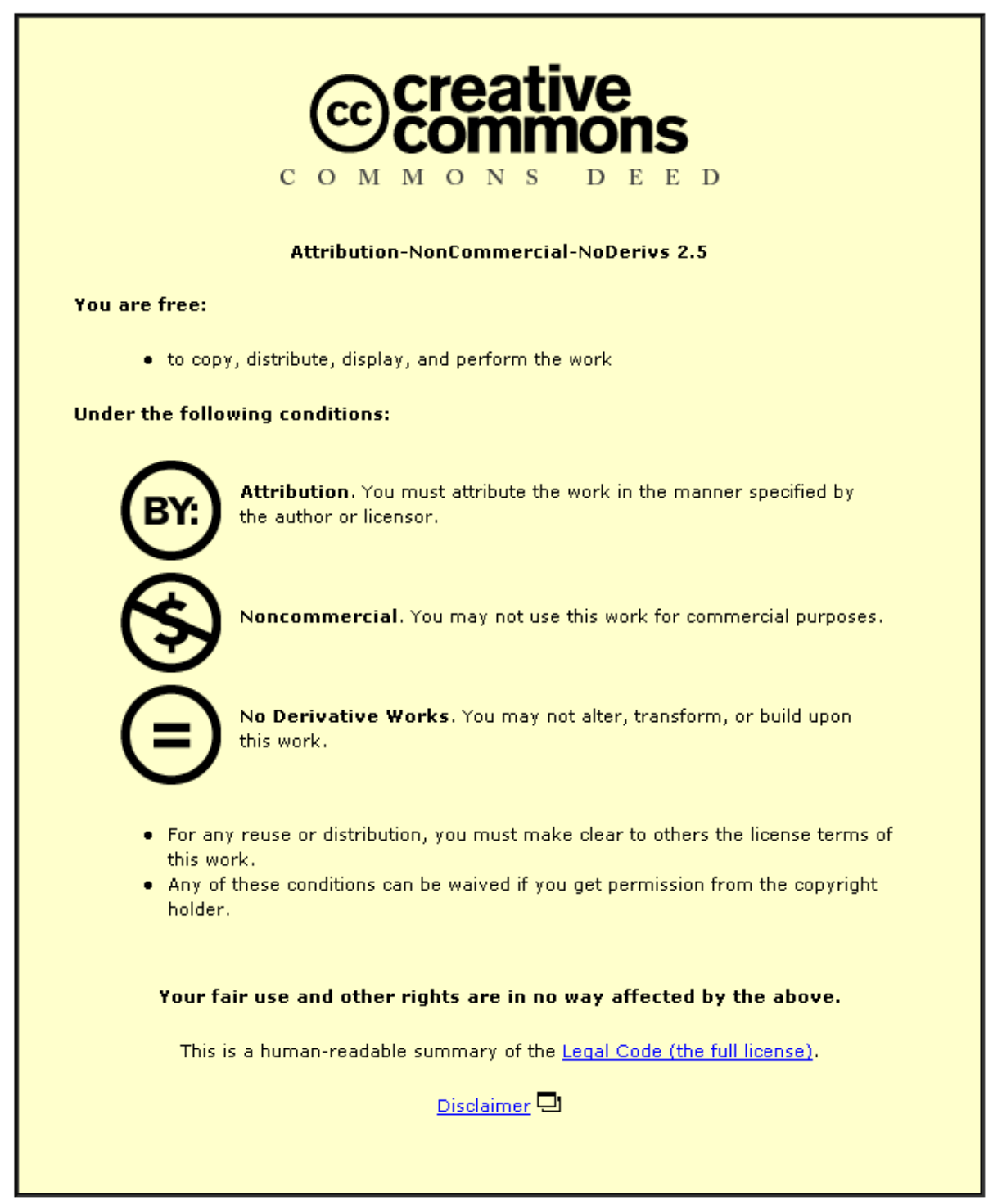

For the full text of this licence, please go to: http://creativecommons.org/licenses/by-nc-nd/2.5/ 


\author{
Wayne Lord \\ Lecturer of Construction Law \\ School of Civil and Building Engineering \\ Loughborough University \\ w.e.lord@Iboro.ac.uk
}

\author{
Tom Gray \\ Quantity Surveyor \\ DAQS Ltd \\ Tollerton UK \\ tg@daqs.co.uk
}

\begin{abstract}
Purpose - The purpose of this paper is to examine relevant case law governing the failure and/or success of global or rolled-up claims, where it is said to be impractical or impossible to demonstrate the links between certain causes of action and the monetary value to be attached to each. The paper proposes a theoretical framework to improve a claimant's prospects of success in advancing a global claim, not only in circumstances where it may be impractical or impossible to provide a breakdown but also where a cost benefit analysis concludes it is reasonable to do so.
\end{abstract}

Design/methodologylapproach - The paper uses traditional doctrinal legal methodology to evaluate judicial statements on the merits of global claims from a number of jurisdictions. The paper also draws on key authorities from the realms of health and safety and professional negligence.

Findings - The cases demonstrate attempts by the court to recognise the problems faced by claimants at the end of a construction contract where their total costs exceed the agreed contract price. The comparative success or failure of a global claim depends on the judicial approach to a number of factors including: impossibility, impracticability, conduct of the claimant and defendant, balance between excessive particularity and basic information, the keeping of records, the costs of claim preparation and apportionment. There remains a significant risk of failure of a global claim but the risk can be reduced significantly provided the claimant conducts a defensible cost benefit analysis of the approach taken.

Practical implications - A global claim can be used more often provided the rationale behind its presentation forms a logical basis. The cost of litigating complex construction contracts can be reduced significantly if global claims can become the norm rather than the exception, provided the claimant conducts a cost benefit analysis and the court concludes the analysis is reasonable and defensible.

Originality/value - Traditional legal theory relies upon the proposition that the claimant must prove that to which he believes he is entitled to such an extent that the defendant's right to know the case it has to meet is satisfied. This paper adds value to the theory by proposing a radical strategy whereby a reasonable claimant can assist the court in finding a factual and logical basis for awarding the whole of a global claim and, where appropriate, by deduction in addition to the principle of apportionment, less than the whole.

Keywords - global claims, cost benefit analysis, litigation, causation

Category - Research Paper 


\section{Introduction}

This paper uses traditional doctrinal legal methodology to evaluate judicial statements on global claims, drawing on key authorities from a number of jurisdictions and from the realms of health and safety law and professional negligence. The purpose of this paper is to examine relevant case law governing the failure and/or success of global or rolled-up claims. It proposes a theoretical framework to improve a claimant's prospect of success in advancing a global claim, not only in circumstances where it may be impractical or impossible to provide a breakdown but also where a cost benefit analysis concludes it is logical and reasonable to do so. Global claims, if advanced correctly, could significantly reduce the costs of litigating complex construction disputes.

\section{The starting point}

The general rule as regards a claimant being compensated in damages for breach of contract was set out by Lord Blackburn in these terms:

'in settling the sum of money to be given for reparation of damages you should as nearly as possible get at that sum of money which will put the party who has been injured, or who has suffered, in the same position as he would have been in if he has not sustained the wrong.'[1]

In other words, the wronged party, so far as money can do it, should be placed in the same position as if the contract had been performed.

Contractors may find themselves in the position of having suffered a loss on a particular project and consider the whole of that loss is attributable to breaches of contract by the client. Contractors may then proceed, in a seemingly generalised and simplistic way, to present a claim for the total "loss" as a measure of damage which should compensate them for the harm suffered.

The claimant's right to be compensated for harm done should also be balanced up with the rights of the defendant as set out by Lord Justice Saville:

'The basic purpose of pleadings is to enable the opposing party to know what case is being made in sufficient detail to enable that party properly to prepare to answer it.'[2]

\section{The global claim authorities}

Global or 'rolled up claims' occur when the claimant presents a claim with no breakdown in the sense that, rather than showing how each individual event has caused delay together with the monetary loss attached to each delay, the claimant provides a single claim lumping each alleged cause together without itemisation. Such an approach under normal circumstances:

'is the antithesis of a claim where the causal nexus between the wrongful act or omission of the defendant and the loss of the plaintiff has been clearly and intelligibly pleaded.'[3]

Lord Humphrey LLoyd QC also went on to say:

'However, that nexus need not always be expressed since it may be inferred. As Lord Oliver emphasised in Wharf Properties there must be a discernable nexus between

[1] Livingston v Rawyards Coal Co (1880) 5 App Cas.25, 39

[2] British Airways Pension Trustees Limited (Formerly Airways Pension Fund Trustees Limited) v Sir Robert McAlpine \& Sons Limited \& ORS [1994] 72 BLR 26, CA

[3] Bernhard's Rugby Landscapes v Stockley Park Consortium (1997) 82 BLR 39 para. 131 
the wrong alleged and the consequent delay (or money) for otherwise there will be no "agenda" for the trial.'[4]

Awards given on a global basis have been supported in the context of

'an extremely complex interaction .......[where] it may be difficult or even impossible to make an accurate apportionment of the total extra cost between the several causative events'[5]. (emphasis added)

The arbitrator in Crosby v Portland also used the word "impractical". Similar words were used by Vinelott $\mathrm{J}$, where he indicated:

'a rolled up award can only be made in a case where the loss or expense attributable to each head of claim cannot in reality be separated and . . . . where apart from that practical impossibility the conditions which have to be satisfied before an award can be made have been satisfied in relation to each head of claim'[6] (emphasis added)

Awards made by both arbitrators and adjudicators on a global basis have been supported by the courts[7]. There have however been notable failures. An argument commonly cited against the global approach is that it amounts to an abuse of process, such an argument usually being presented at an interlocutory stage in the form of an application to strike out the claim. The abuse can be categorised as where the claimant provides no particularisation to a claim such that the defendant does not know what he is defending himself against. In Wharf $v$ Cumine Associates[8], the claimant had submitted a four hundred page document without stating their exact position and without identifying the key cause of delay. In responding to an application to strike out, the claimant then stated that

'It will be necessary at trial to consider all variations instructed in order to establish which of them are unnecessary'.[9]

The court then concluded;

'The failure even to attempt to specify any discernable nexus between the wrong alleged and the consequent delay provides, to use Mr Thomas's phrase [counsel for the defendants] "no agenda for the trial".'[10]

While Wharf could be argued to be the low point for global claims, in Mid Glamorgan $v$ Devonald Williams[11] the court reiterated the view that global claims were permissible in situations where there were issues of impossibility or impracticability:

'Where however a claim is made for extra costs incurred through a delay as a result of various events whose consequences have a complex interaction that renders specific relation between event and time/money consequence impossible or impracticable, it is permissible to maintain a composite claim. '[12] (emphasis added)

From Wharf onwards we can see the courts reluctance to strike out global claims purely because they were presented as global claims.

The District Court of Western Australia (2007) defines the nature of a Scott Schedule as being a form of pleading which allows the court to have before it a single document. That

[4] Bernhard's, note 3

[5] Crosby and Sons Ltd v Portland UDC (1967) 5 BLR 121, QBD

[6] London Borough of Merton v Stanley Hugh Leach Ltd (1985) 32 BLR 51 pp. 102-103

[7] Crosby, note 5 and Shell Refining (Australia) Pty Limited v AJMayr Engineering Pty Limited [2006] NSWSC 94

[8] Wharf Properties Ltd v Eric Cumine Associates [1991] 52 BLR 1

[9] Wharf, note 8

[10] Wharf, note 8

[11] Mid Glamorgan County Council v J Devonald Williams (1991) 8 Const LJ 61, QBD (OR)

[12] Mid Glamorgan, note 11 
document conveniently providing a full description of each element of claim together with the adopted positions of each party (in terms of admission or denial and quantum/evidence) to each element. In ICI v Bovis the claimant produced four volumes to present its case in the form of a Scott Schedule.

'The objectives sought to be achieved by the Court in orders made relating to Scott Schedules are to ensure that when the action is entered for trial: each individual item claimed is particularised ... the amount asserted by both parties ... the contentions of each parties ... areas of agreement relating to the description of the item and quantum ... the aggregate of the claims and areas of admissions of each party are known.'[13]

The claim in $\mathrm{ICl} v$ Bovis was still found to be deficient in many respects but permitted to proceed without further and better particulars being required. The claimant's claim in British Airways Pensions Trustees $v$ Sir Robert McAlpine[14] (on appeal from a successful strikeout application) was acknowledged by the court as seriously defective in failing to particularise the basis of the claim, yet was allowed to proceed with further and better particulars being required. To the other extreme was the Australian case of John Holland v Kvaerner[15] where the pleadings showed no nexus between the events claimed of and the loss and damage alleged but still allowed to proceed provided further and better particulars were produced.

Consideration was given as to how far the claimant must go in particularising his claim in the case of Bernhard's Rugby Landscapes $v$ Stockley Park[16]. Judge Humphrey LLoyd, having reviewed the authorities, restated the principles of a global claim and, while maintaining the proposition that the claimant is entitled to present its case as it thinks fit, the court must ensure a party spells out its case in sufficient particularity in order to ensure fairness and observance of the rules of natural justice. Judge Humphrey LLoyd went on to say:

'What is sufficient particularity is a matter of fact and degree in each case, with a balance being struck between excessive particularity and basic information. The approach must also be cost effective.'[17] (emphasis added)

The Court of Appeal concluded that the core dispute, over pleadings and case management, in Petromec Inc v Peroleo Brasileiro SA[18] concerned the degree of particularity with which Petromec must plead its case. The dispute raised questions of fairness, practicality and the appropriate means of enabling the court to define and decide issues between the parties. The court concluded that 'it would not be fair to Petrobras, nor a practical way of the court proceeding, if Petromec were not required to give adequate particulars of their claim.'[19] (emphasis added)

Lord Woolf and Lord Justice Otton heard an appeal against the refusal of a late strikeout application of a poorly pleaded global claim in the case of GAB Robins $v$ Specialist Computer Centres[20]. The appeal was refused. Lord Woolf acknowledged that the case should have taken a different direction. He also expressed some sympathy for the trial judge and expressed hope that the judge would take into account the contribution the poor pleadings may have had on whether, to use the earlier words of Lord Justice Otton (citing with approval Judge LLoyd in Bernhard's Rugby Landscapes v Stockley Park), the court's fundamental concern that the dispute should be determined "expeditiously and economically"[21] had been addressed.

[13] ICI PlC v Bovis Construction (1992) 8 Const LJ 293

[14] British Airways . note 2

[15] Holland Construction and Engineering Pty Ltd v Kvaerner RJ Brown Pty Ltd (1996) 82 BLR 83

[16] Bernhard's Rugby, note 3

[17] Bernhard's Rugby, note 3 para. 138

[18] Petromec Inc v Petroleo Brasileiro S.A. Petrobras \& ors [2007] EWCA Civ 1371

[19] Petromec, note 18 para. 31

[20] GAB Robins Holdings Ltd v Specialist Computer Centres Ltd [1998] EWCA Civ 924 (8 June 1998)

[21] GAB Robins, note 20 
There are warnings against the danger of a global claim failing completely if any significant part of the delay is not established and the court finds no basis for awarding less than the whole (Keating, 2006).

In John Doyle $v$ Laing, Lord McFadden indicated that "advancing a claim for loss and expense in global form is therefore a risky enterprise"[22]. The risk being the global claim is undermined if either the claimant fails to prove that a material event was the fault of the defendant or, the defendant is able to prove that a material contribution to the global loss was attributable to other factors not attributable to him. Lord McFadden mitigated his analysis by providing two considerations:

'The first of these is that while ...... the global claim as such will fail, it does not follow that no claim will succeed. ...... but there may be in the evidence a sufficient basis to find causal connections .... or to make a rational apportionment of part of the global loss....

The second factor ...... is that causation must be treated as a commonsense matter.'[23] (emphasis added)

In terms of awarding less than the whole, Lord McFadden made it clear that "if a lesser claim is to be made out, that must be done on the basis of the evidence which is properly led within the scope of the existing pleadings."[24]

The American courts have considered total cost claims and awarded less than the whole. In Servidone $v$ the United States, the claimant:

'presented evidence under the total cost method. Servidone, 19 Cl.Ct. at 384. Under this method, the contractor must show: (1) the impracticability of proving actual losses directly; (2) the reasonableness of its bid; (3) the reasonableness of its actual costs; and (4) lack of responsibility for the added costs. '[25]

In finding that the claimant's bid (Servidone) was unreasonable, the Claims Court applied a modified total cost method and 'substituted a reasonable bid amount for Servidone's original estimate.' The court also considered the effect on contractor's costs of 'performance inefficiencies.' [26]

Judge Thornton asked a number of questions in How Engineering $v$ Lindner as to how the Lindner claim could be scaled down if some of the causative events alleged had been eliminated or to take account of defects, inefficiencies or events at Lindner's risk[27].

Support for an apportionment process may be found in the words of Mr Justice Donaldson in Crosby who supported the arbitrators strategy in recognising that a claim does not need to be fully global or fully detailed but, that the contractor should particularise where possible and then ascertain his losses through a global claim where it was not possible by saying;

'I can see no reason why he [the arbitrator] should not recognise the reality of the situation and make individual awards in respect of those parts of individual items of the claim which can be dealt with in isolation and a supplementary award in respect of the remainder of those claims as a composite whole.'[28]

[22] John Doyle Construction Limited v Laing Management (Scotland) Limited Outer House, Court of Session [2002] Scot (D) 23/4 para. 37

[23] John Doyle, note 22 paras. 38 and 39

[24] John Doyle, note 22 para. 41

[25] Servidone Construction Corporation v the United States [1991] 931 F.2d 860 United States Court of Appeals, Federal Circuit paras. 9 and 10

[26] Servidone Construction, note 25 paras. 9 and 10

[27] How Engineering Services Ltd v Lindner Ceilings Floors and Partitions plc unreported (QBD (OR), 17 May 1995

[28] Crosby, note 5 
Winter (2007: 11) argues that this type of approach reverses the burden of proof.

In order to prevent the burden of proof being transferred away from the claimant, the claimant may be required to "open his books" and lead evidence to indicate what his own failings might be so that the court can attribute quantum to those failings. The claimant may also be required to lead similar evidence to indicate other issues not the fault of the defendant so that, again, the court can attribute quantum to those liabilities.

A rational apportionment of the global claim or a reasoned deduction from the whole can then be made without, necessarily, reversing the burden of proof.

After this review of the authorities, the following ingredients for a global claim can be distilled:

- Impossible to particularise

- Impractical/ impracticable to particularise

- Material contribution

- Adequate particularity

- Sufficient particularity (a matter of fact and degree)

- Striking of a balance

- Approach must be cost effective

- Dispute determined expeditiously and economically

- Dispute resolved fairly

- Causation a commonsense matter

- Rational apportionment

This paper now discusses key elements of the above ingredients and proposes a framework for global claims with less risk but also proposing that global claims should be used more often as a;

'commonsense approach . . . defeating unmeritorious and inflated claims whilst ensuring the disinterested defendant does not prosper merely because the project was highly complicated, or simply went very wrong indeed. '[29]

\section{Impossible or impractical to particularise}

The Oxford English Dictionary defines impossible, impractical and impracticable respectively as follows:

'Not possible; that cannot be done or effected; that cannot exist or come into being; that cannot be, in existing or specified circumstances.'

'Not practical; unpractical. Also = impracticable'

'Not practicable; that cannot be carried out, effected, accomplished, or done; practically impossible.'

The meanings apparently being interchangeable and absolute.

This paper has considered American authorities and it is worth noting that the definitions of impossible, impractical, impracticable can shed some of their absolute meaning if the meaning of impractical is taken to include the words 'not sensible or realistic' as may be found within the New Oxford American Dictionary 2nd Edition. 
In their Delay and Disruption Protocol, the Society of Construction Law (2002) consider the starting point with any claim is for the claimant to maintain accurate and complete records during the project so that it should be able to establish causal links between events and the loss complained about without need to resort to a global claim. In any event, with or without such records at what point does the question of impossibility arise? Is it at advancement of the claim or at trial? This question may be answered by the words of Lord McFadden in John Doyle:

'The rigour of that analysis is in my view mitigated by two considerations. The first of these is that while, in the circumstances outlined, the global claim as such will fail, it does not follow that no claim will succeed. The fact that the pursuer has been driven (or chosen) to advance a global claim because of the difficulty of relating each causative event to an individual sum of loss or expense does not mean that after evidence has been led it will remain impossible to attribute individual sums of loss or expense to individual causative events.'[30] (emphasis added)

In some cases, the courts have balanced up the needs of the claimant to add to his case by serving further and better particulars in order to assist the defendant to understand the case he has to answer[31].

In considering whether the claimant advances a global claim or not, it should also be recognised that such a claim is 'a risky enterprise'[32] particularly if absolute definitions are given to phrases such as impossible, impractical and impracticable as may be found in various judicial statements made in considering global claims. But we also see some relaxing of the absolute terms when the court uses words such as 'adequate'[33] or 'sufficient'[34] particularity.

\section{Sufficient or adequate particularity}

The seemingly absolute requirement of impossibility could be assimilated with an obligation to use best endeavours. To that end, should a claimant use his best endeavours and "leave no stone unturned'[35] either before he presents his claim or at any time through to trial? Or should he be required to use reasonable endeavours to produce adequate or sufficient particularity?

Although Judge Flaux was not convinced the distinction between best and reasonable endeavours made much difference on the facts of the case before him in Rhodia $v$ Huntsman, he nevertheless addressed his mind to the distinction and drew the following conclusion:

'33. .... am not convinced that .... any of the judges in the cases upon which Mr Beazley relied were directing their minds specifically to the issue whether "best endeavours" and "reasonable endeavours" mean the same thing. As a matter of language and business common sense, untrammelled by authority, one would surely conclude that they did not. This is because there may be a number of reasonable courses which could be taken in a given situation to achieve a particular aim. An obligation to use reasonable endeavours to achieve the aim probably only requires a party to take one reasonable course, not all of them, whereas an obligation to use best endeavours probably requires a party to take all the reasonable courses he can.

[30] John Doyle, note 22 para. 38

[31] See $I C I$, note 13, British Airways note 2 and Holland note 15

[32] John Doyle, note 22

[33] Petromec, note 18 para. 31

[34] Bernhard's Rugby, note 3 para. 138

[35] Sheffield District Railway Co v Great Central Railway Co (1911) 27 TLR 451 at p. 452. 
In that context, it may well be that an obligation to use all reasonable endeavours equates with using best endeavours ....

'35. Accordingly, in so far as it is necessary to decide this point, I agree with $\mathrm{Mr}$ Edwards-Stuart that an obligation to use reasonable endeavours is less stringent than one to use best endeavours. As to what reasonable endeavours might entail, he relied upon a recent decision of Lewison $\mathrm{J}$ in Yewbelle $v$ London Green Developments [2006] EWHC 3166 (Ch) at paragraphs 122-3 where the judge concluded that Yewbelle was not required to sacrifice its own commercial interests. '[36]

Judge Flaux appeared to conclude that best endeavours equated to all reasonable endeavours and that reasonable endeavours was a lower requirement. Some consideration as to the cost consequences of each was not considered except in terms of sacrificing and/or acting against the parties' own commercial interests.

Time, trouble and expense are factors to be taken into consideration when weighing up whether statutory defences in health and safety law are proven.

In Coltness Iron Co v Sharp, Lord Atkin said:

'the time of non protection is so short, and the time, trouble and expense of any other form of protection is so disproportionate that I think the defence is proved. '[37]

In Edwards v National Coal Board, the Court of Appeal gave broad support to Lord Atkin's construction of the phrase 'reasonably practicable'. In particular, Lord Justice Asquith came to the conclusion that:

"Reasonably practicable" is a narrower term than "physically possible" and seems to me to imply that a computation must be made by the owner, in which the quantum of risk is placed on one scale and the sacrifice involved in the measures necessary for averting the risk (whether in money, time or trouble) is placed in the other; and that if it be shown that there is a gross disproportion between them ... the defendants discharge the onus on them. '[38]

Here we see some discussion of a balance being struck and a question of proportionality (albeit "gross proportionality"). The health and safety authorities and published guidance do not appear to define what constitutes the distinction between proportionality or gross proportionality. What is clear in relation to the duties of a designer under the Construction (Design and Management) Regulations 2007 is that those duties to perform "so far as is reasonably practicable" is qualified by having to take

'due account of other relevant design considerations"[39] and, according to CDM ACOP (Managing Health and Safety in Construction, 2007), in doing so the designer should "weigh the various factors and reach reasoned, professional decisions'[40]

\section{The striking of a balance}

Direct guidance is provided by the Health and Safety Executive (2007) in their Policy Statement on Enforcement as to their approach to enforcement of health and safety law in particular:

[36] Rhodia International Holdings Ltd. Rhodia UK Ltd. v Huntsman International Plc [2007] EWHC 292 (Comm) at para. 35

[37] Coltness Iron Company v Sharp (1938) AC 90, 94

[38] Edwards v National Coal Board (1949) 1 KB 704 p. 712

[39] regulation 11

[40] para. 124 
'10. The HSE believes in firm but fair enforcement of health and safety law. This should be informed by the principles of proportionality in applying the law and securing compliance ......

11. Proportionality means relating enforcement action to the risks ....

14. Deciding what is reasonably practicable to control risks involves the exercise of judgement.'[41]

Even though the obligation appears to be akin to an absolute obligation in health and safety law i.e. to comply so far as is reasonably practicable, there appears to be an element of proportionality and the exercise of judgement.

The standard to be expected of a professional in exercising judgement may be found in the widely recognised direction to the jury set out by Judge McNair in Bolam v Friern Hospital Management:

'the standard of the ordinary skilled man exercising and professing to have that special skill..... It is well established law that it is sufficient if he exercises the ordinary skill of an ordinary competent man exercising that particular art... as long as it is remembered that there may be one or more perfectly proper standards; and if a medical man conforms with one of those proper standards then he is not negligent.'[42]

A professional is required to exercise the ordinary skill of a competent respected practitioner in his field and will not be:

'guilty of negligence if he has acted in accordance with a practice accepted as proper by a responsible body of medical men skilled in that particular art'[43].

The Bolam test was considered by the House of Lords in Bolitho $v$ Hackney Health Authority[44] with the test being modified such that the court is required to ask whether 'the body of opinion relied on can demonstrate that such opinion has a logical basis'. In particular, the House of Lords also concluded that there must be a 'weighing of risks against benefits, ... the Judge .... will need to be satisfied that .... the experts have directed their minds to the question of comparative risks and benefits and have reached a defensible conclusion on the matter.'[45]

This paper proposes that even where there are seemingly absolute definitions, the court leans towards a cost benefit analysis. Specifically with regard to global claims, Judge Thornton stipulated that the approach to providing sufficient particularity must be 'cost effective'[46].

\section{The Jackson Review}

Judge Thornton considered Amec's behaviour as against the overriding objectives of the Civil Procedure rules in determining whether its costs were reasonable or unnecessary:

'It is clear that Amec acted reasonably in taking decisions which, in effect, sought to give effect to these overriding objectives. Given the size of the tasks and the

\footnotetext{
[41] see page 3

[42] Bolam v Friern Hospital Management Committee [1957] 2 All ER 118

[43] Bolam, note 42

[44] Bolitho v City and Hackney Health Authority (1997) UKHL 46

[45] Bolitho $v$ City and Hackney Health Authority (1997) UKHL 46

[46] Bernhard's Rugby, note 3 para. 138.
} 
uncertainties involved, Amec is not necessarily to be faulted if some of the steps taken can be seen with hindsight to have been unnecessary or involved unnecessary expenditure. In considering whether Amec should be entitled to all or the major part of its reasonably incurred costs, it is necessary to test the steps that were taken by reference to their reasonableness taken against this background. '[47]

Building on the principles of access to justice enshrined in the Civil Procedure Rules, The Jackson Review (2009) linked access to justice, proportionate costs and practicable coming to the conclusion that:

'Proportionate costs make access to justice practicable. Access to justice is only practicable if the costs of litigation are proportionate. '[48]

The Jackson Review set out guidelines to help the Rules Committee to formulate a definition of proportionate costs which, he hoped, would bear a reasonable relationship with such matters as: the sums in issue; complexity; any additional work generated by the conduct of the paying party[49]. He also considered that oppressive conduct by wealthy litigants in putting their opponents to excessive and disproportionate costs should be sanctioned by indemnity costs with the proposed definition of proportionate costs protecting a receiving party even where indemnity costs are not awarded[50]. What is also important to consider is that Lord Justice Jackson went on to say:

'The policy which underlies the proposed new rule is that cost benefit analysis has a part to play, even in the realm of civil justice.'[51] (emphasis added)

So both a claimant and a defendant are required to conduct a cost benefit analysis as to the detail and extent of their pleadings and evidence. This is particularly relevant to construction claims which can be voluminous especially where Scott Schedules are required.

\section{The Framework}

The claimant and the defendant should conduct a defensible cost benefit analysis before deciding on which combination of steps set out below, or any combination of them, is chosen in order to assist the court to come to a cost effective determination of the issues in dispute between them:

1. All causative events the responsibility of the Defendant

a. Prepare whole of claim with sufficient particularity to ensure Defendant knows the case he has to meet.

b. Where not all the elements are capable of particularisation, provide sufficient particularity for those parts that can be and globally claim the rest.

2. Some causative events not the responsibility of the Defendant

a. Prepare whole of claim with sufficient particularity to ensure Defendant knows the case he has to meet and identify those elements (with a quantum range) that may not be the Defendant's liability,

b. Isolate those elements of claim that can be attributable to the Defendant and provide sufficient particularity where it is possible to do so. Globally claim the rest and identify those elements (with a range of quantum) that may not be the Defendants liability.

c. Ensure sufficient evidence is properly led to enable the court to apportion and/or reduce the value of any globally claimed elements. This may include

[47] Amec Process and Energy Ltd v Stork Engineers \& Contractors BV (No 3) [2002] All ER (D) 48 (Apr) para.

26

[48] see Part 1 Chapter 4 para. 2.5

[49] see Part 1 Chapter 3 para. 5.15

[50] see Part 1 Chapter 3 para. 5.21

[51] see Part 1 Chapter 3 para. 5.17 (citing AB v John Wyeth and Brothers Ltd, CAT 13 December 1996) 
open book type consideration of tender costs and/or performance inefficiencies and/or defects that are the claimant's responsibility. The evidence to be led should enable the court to conduct an appropriate apportionment or make an appropriate deduction without reversing the burden of proof.

\section{Conduct}

This paper closes on the discussion of a proposed framework by providing a reminder of what happened in Wharf and the effect of conduct on the outcome of proceedings in global claim cases. Wharf had been ordered to, and agreed to provide further and better particulars using Scott Schedules, which they did not do. To that extent, it could be argued that the failure of the global claim in this instance was not a matter of principle in respect of global claims but procedural failure and a matter of conduct of the claimant.

Conduct of the claimant was also considered in Merton $v$ Leach:

'at the time when loss or expense comes to be ascertained it is impractical to disentangle or disintegrate the part directly attributable to each head of claim, then provided that the contractor has not unreasonably delayed the making of the claim and so has himself created difficulty the architect must ascertain the global loss directly attributable to the two causes'[52] (emphasis added)

The courts also commented on the behaviour of the claimant in ICI v Bovis[53]:

'the contents of these four volumes leave no doubt that very considerable work has been done in their preparation. There is a total lack of any contumelious behaviour on the part of $\mathrm{ICl}$ or its advisors. '[54]

It would appear the Judge had certain sympathy to ICl's situation however, despite ICl's considerable work the defendant was still not fully aware of the case they had to meet. Wharf was reconsidered; their Lordships commented that if a pleading was to embarrass the fair process of trial, it could not be considered in isolation from the litigation history. Wharf had lasted seven years and they had conceded their claim needed further particularisation, which they failed to do and were criticised for that failure. In contrast, $I C I$ had put considerable work into proceedings that had been active for a much shorter period i.e. two years and were continually praised. The decision in $\mathrm{ICI}$ could therefore be applauded for its pragmatism.

The courts commented on the behaviour of the defendant in Inserco $v$ Honeywell Control Systems:

'Inserco ought never to have been compelled to start these proceedings, and certainly should have not had to endure a trial of this length and complexity in which issues raised by the defence were extensively explored, which had little merit and no apparent commercial justification, and in which Inserco were faced with counter claims which are bound to fail in whole or in part as the necessary evidentiary or legal foundation for them either did not exist or was not adduced. '[55]

The defendant also came under fire in the Court of Appeal:

'I am very doubtful whether there is a definable point of law raised by this appeal. In view of the fact that the investigation was so prolonged and profound, and resulted in

[52] London Borough of Merton, note 6

[53] ICI v Bovis Construction and others (1992) 32 ConLR 90

[54] $\mathrm{ICl}$, note 53

[55] Inserco v Honeywell Control Systems (1998) CILL 1368, CA 
the fullest of judgements, it is to be regretted that it has been brought to this court for review on such a slender foundation'[56]

The conduct of the defendant also came under scrutiny in the case of Amec Process $v$ Stork Engineers[57]. Amec had suffered substantial delay and costs for numerous reasons including changes, variations and lack of information. During the early stages of the dispute between the parties, Amec produced substantiation for their contentions in the form of sample schemes. This type of substantiation was rejected by Stork and Amec were forced to bring their claim to the courts for resolution. Amongst other criticisms of the defendant, Judge Thornton dismissed Stork's procedural objections stating:

'Given (1) the nature of Amec's case at trial, (2) the decoupling of the schedules from the pleadings and (3) the many detailed agreements reached by the experts on the instructions, and with the full agreement, of both parties, a fair trial was both possible and manageable.'[58]

Amec were ultimately successful with their largely global claim. On the question of costs, Judge Thornton concluded that the defendant had: rejected the claims without any detailed reasoning; rejected mediation; failed to react proactively when the claimant had prepared and pleaded its case, failed to plead in detail in its defence and sought to make general and unsubstantiated assertions in attempts to prolong the litigation. Judge Thornton criticised 'Stork's continuous and obstructive obfuscation'[59] as being at the heart of its failure to produce evidence which contributed greatly to the time and costs Amec expended in preparing and presenting the case by both sides. Judge Thornton considered this case to fall within 'one of those exceptional cases where indemnity costs should be awarded even if there is no disapproval of Stork's conduct.'[60] Judge Thornton nevertheless, disapproved of the manner in which Stork's overall case was presented. Amec were therefore awarded indemnity costs in addition to being successful with their global claim.

The criticisms levelled at the defendants in Inserco v Honeywell[61] and Amec v Stork[62] are arguably at the heart of the Jackson Review's discussion on prolix pleadings (with specific reference to TCC proceedings) which centred around re-pleading and/or disallowing costs at the end of the case[63]. Lord Justice Jackson suggested that the TCC Guide be amended to give power to the court to disallow costs where pleadings or witness statements contained extensive irrelevant or peripheral material with further emphasis on focussing on key issues at Pre-Trial Review[64].

\section{Conclusion}

The basic premise for presenting a claim in whatever form, whether it be a global claim in whole or in part, is that the defendant needs to know the case he has to meet so that there may be a fair trial of the issues. The global claim authorities appear to indicate that the claimant need only present his claim in sufficient or adequate particularity providing a balance is struck between a claimants' right to be compensated and a defendants' right to be able to respond. Those authorities also indicate that the claim needs to be dealt with expeditiously and economically and in a cost effective manner.

The trend in other areas of law, including health and safety and professional negligence, is that there needs to be a cost benefit analysis approach to the exercise of judgement in any

[56] Inserco, note 55

[57] Amec Process and Energy Ltd v Stork Engineers \& Contractors BV [2002] All ER (D) 98 (Feb)

[58] Amec, note 57

[59] Amec note 47 para. 84

[60] Amec note 47 para. 85

[61] Inserco note 55

[62] Amec note 57

[63] Part 5 Chapter 29 para. 2.2

[64] Part 5 Chapter 29 para. 6.1 
decisions taken. The recent Jackson review adds further support to the cost benefit analysis to civil justice.

This paper concludes that a cost benefit analysis requires a claimant to present his claim with sufficient particularity. Where that cost benefit analysis is defensible and can demonstrate the advancement of a global claim is cost effective so that the trial would be fair, a global claim should be the norm for all claims. This is particularly so where it can be demonstrated that all the events complained of are the fault of the defendant. The approach may nevertheless require the claimant to particularise those elements of the claim which are related to key issues.

A claimant does however need to ensure that he cannot be criticised for either asking the court to do his work for him and/or seek to reverse the burden of proof onto the defendant. In order to do that, a claimant may be permitted greater opportunity to present a global claim, even where there are elements that are not the defendants fault, provided always that the claimant opens up his books to be scrutinised in order to provide the court with appropriate evidence to show that a rational apportionment can be made and/or to particularise those elements that are not the fault of the defendant. To assist the court, the claimant should lead evidence and provide sufficient particularity with a breakdown of those elements that may be attributable to inefficiencies in the claimants own claim or low bid costs or to third parties or to events that are the fault of neither party. If there are any uncertainties present with individual parts of the claim, the claimant should separate those parts of the claim to prove the absolute integrity of their case. In a sense, the claimant should be "whiter than white". It may prove fatal to the claimants case if he does not lead evidence in the manner proposed.

If a claimant conducts his case in this way, the court may be in a position to apportion upwards on certain elements, if it is felt to be correct at trial.

With an appropriate cost benefit analysis, it may be cost effective to present even a claim that can be particularised as a global claim provided there is sufficient particularisation of a deduction, from the globally claimed amount, with ranges of quantum attached to the particulars so that the court can see that the claimant has come to a reasoned conclusion on presenting his claim. A defendant should, nevertheless, be wary of seeking further particularity where it is not really necessary and it remains clear to the court the defendant is reasonably aware of the case he has to meet.

The Jackson review on costs, when implemented, should also provide sufficient safeguards to protect both claimants' and defendants' against unreasonable conduct of the other to support the conclusions of this paper. 


\section{References}

The Construction (Design and Management) Regulations, 2007. SI 2007 No. 320. www.legislation.gov.uk

District Court of Western Australia, 2007. Scott Schedules, Circular to Practitioners CIV 2007/3. 3 August 2007. www.districtcourt.wa.gov.au/_files/Circular to Practitioners 2007-3 Scott Schedules.pdf last accessed 3 June 2011

Health and Safety Executive's Policy Statement on Enforcement, 2009. Available at www.hse.gov.uk/pubns/hse41.pdf last accessed 9 February 2011.

Jackson, R. "Review of Civil Litigation Costs - Final Report" 2009 (The Jackson Review). HMSO, London.

Keating on Construction Contracts 8th Edition edited by S. Furst and V Ramsey, 2006.

Sweet and Maxwell, London 2006

Managing health and safety in construction, 2007. Construction (Design and Management) Regulations 2007. CDM Approved Code of Practice. L144, HSE Books.

Oxford English Dictionary, 2011. Oxford University Press. Online version accessed 7 February 2011 www.oed.com.

New Oxford American Dictionary 2nd Edition. Oxford University Press USA, 2005. Kindle ebook accessed 7 February 2011.

The Society of Construction Law Delay and Disruption Protocol, October 2002 available from http://www.scl.org.uk/resources

Winter, J (2007). "Global Claims and John Doyle v Laing Management - Good English Law? Good English Practice? Paper 140, Society of Construction Law. July 2007. Available from http://www.scl.org.uk/papers 